\title{
磯根水産生物の着定基質用石材の耐波安定性 \\ STABILITY OF RUBBLE MOUND HABITAT \\ FOR ROCKY SHORE FISHERIES RESOURCES
}

\author{
谷野賢二 ${ }^{1} \cdot$ 木村克俊 ${ }^{2} \cdot$ 林倫史 $^{3} \cdot$ 桑原伸司 ${ }^{4} \cdot$ 清野克徳 $^{3} \cdot$ 伊東雅規 ${ }^{3}$ \\ Kenji YANO, Katsutoshi KIMURA, Michifumi HAYASHI, \\ Shinji KUWABARA, Katsunori SEINO and Masaki ITO \\ ${ }^{1}$ 正会員 工博 北海道東海大学教授 工学部海洋開発工学科（广005-8601 札幌市南区南の沢 5 条 1 丁目） \\ 2 正会員 工博 室蘭工業大学助教授 工学部建設システム工学科（T050-8585 室蘭市水元町 27-1） \\ ${ }^{3}$ 正会員 北日本港湾コンサルタント株式会社 技術部 環境・水理課 \\ （于003-0029 札幌市白石区平和通 2 丁目北 11 番 18 号） \\ ${ }^{4}$ 正会員＼cjkstart北日本港湾コンサルタント株式会社＼cjkstart技術部次長 \\ （厂003-0029 札幌市白石区平和通 2 丁目北 11 番 18 号）
}

\begin{abstract}
The stability of stones for a rubble mound used as a habitat for rocky shore fisheries resources was examined by two-dimensional hydraulic model experiment using irregular waves. We examined the scattering characteristics of stone by changing the structure of the mound and the waves conditions. Based on the results we proposed a calculation method of stable weight of stone materials for rubble mound habitat. The stability number Ns was formulated as a function of the ratio of water depth to wave length. We also examined the influence of weight distribution of stone materials on the mound stability.
\end{abstract}

Key Words : Rocky shore fisheries resources, stability of rubble mound habitat

\section{1. まえがき}

現在、浅海漁業において重要な水産資源であるコ ンブなどの海藻類やアワビ, ウニ類などの海産生物 資源は減少傾向にある。このため、これまでの漁業 場整備開発事業の一環として実施されている増殖場 の造成がある。 形態に加え「つくり育てる漁業」が盛んに行われ、 種苗放流をはじめとする漁業管理の強化および漁場 造成など資源回復の試みが数々行われている。また、 資源増加のため港湾, 漁港の開発においても周辺の 生態系との調和・共存を考慮することが求められて いる。こうした水産資源増加の手法の一つに沿岸漁
図ー 1 は北海道乙部地区に整備されたエゾバフ ンウニを対象とした増殖場を示している。一辺が約 $20 \mathrm{~m}$ 正方形の増殖場が水深 $3 \sim 8 \mathrm{~m}$ の範囲に配置 されている。その構造は図ー 2 に示すように、異型 ブロックで周りを囲い(囲礁)、その中に対象生物の 着定基質となる石材を敷き並べる形式が一般的であ る。 


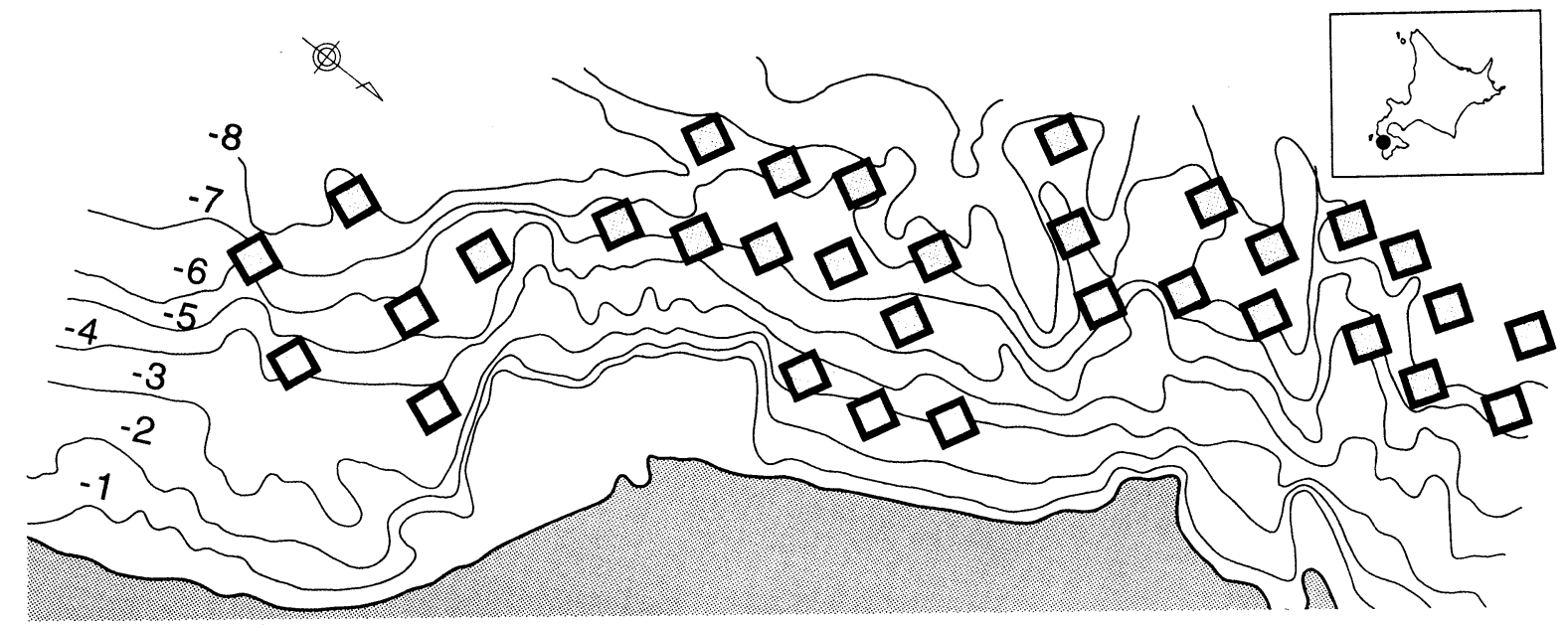

図-1 増殖場の配置例（北海道乙部地区）

unit:m

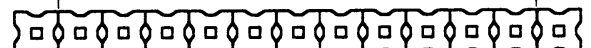

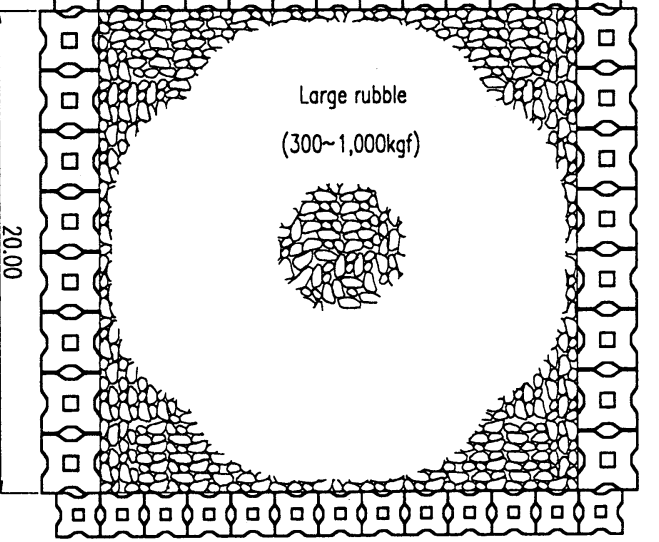

H.W.L +0.40

L.W.L \pm 0.00

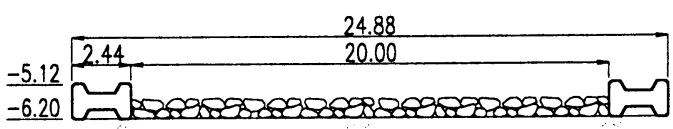

図 -2 増殖場の構造形式（北海道乙部地区）

現状では石材の質量は沿岸漁場整備開発事業施 設設計指針（1993）1）によって算定されている。こ

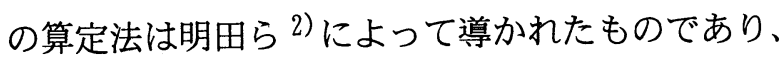
安定質量が波浪による発生流速の 6 乗に比例する形 式となっているため、条件によっては計算值が過大 となる場合がある。また、規則波実験結果に基づい て定式化されているため、作用波数や被害率の影響 が考慮されていないなどの課題がある。

本研究では、不規則波を用いた安定実験により、 一般的な着定基質用石材の移動特性を明らかにし、 その安定質量算定法を提案する。

\section{2. 北海道内における施工事例}

表一 1 は北海道内におけるウニやコンブを対象 とした増殖場の施工例について、水産庁による調査 報告書 2）などを参照してまとめたものである。17 例のうち半数以上が水深 $5 \mathrm{~m}$ 以内の比較的浅海領域 に施工されている。また、石材は $30 \sim 1,000 \mathrm{~kg}$ 程度 の中割石や大割石を用いる場合が多く、積層厚は $0.6 \sim 0.9 \mathrm{~m}$ が標準的であった。

表 -1 増殖場の施工例

\begin{tabular}{|c|c|c|c|c|c|c|}
\hline \multirow[b]{2}{*}{ 海域 } & \multirow[b]{2}{*}{ 地区 } & \multirow[b]{2}{*}{ 対象生物 } & \multirow{2}{*}{$\begin{array}{c}\text { 設置水深 } \\
(\mathrm{m})\end{array}$} & \multicolumn{2}{|c|}{ 捨石諸完 } & \multirow{2}{*}{ 囲礁 } \\
\hline & & & & $\begin{array}{l}\text { 㙺量 } \\
(\mathrm{kg})\end{array}$ & $\begin{array}{c}\text { 掼層倡 } \\
(\mathrm{m})\end{array}$ & \\
\hline \multirow{9}{*}{ 太平洋 } & 浦河 & $\begin{array}{l}\text { エソパフンウニ } \\
\text { ミツイシコンブ }\end{array}$ & $1.7 \sim 4$ & - & 0.6 & 0 \\
\hline & 浦河東部 & ミツイシコンブ & $2 \sim 5$ & $300 \sim$ & 0.9 & 0 \\
\hline & 釧路東部 & ナガコンブ & $3 \sim 6$ & $300 \sim 1.000$ & 0.9 & O \\
\hline & 函馆 & マコンブ & $6 \sim 8$ & $300 \sim 1,000$ & 0.9 & - \\
\hline & $\begin{array}{c}\begin{array}{c}\text { 知内·福 } \\
\text { 島 }\end{array} \\
\end{array}$ & エソハパフンニ & $2 \sim 5$ & $\begin{array}{c}300 \sim 1,000 \\
30 \sim 300\end{array}$ & $\begin{array}{l}0.9 \\
0.6\end{array}$ & 0 \\
\hline & $\begin{array}{l}\text { 南茅部 } \\
\text { 北部 }\end{array}$ & マコンブ & $4 \sim 10$ & $300 \sim$ & - & O \\
\hline & 椴法華 & マコンブ & $7 \sim 11$ & $300 \sim$ & - & 0 \\
\hline & 伊達 & マコンブ & $4 \sim 5$ & $300 \sim 1,000$ & 0.9 & 0 \\
\hline & \begin{tabular}{|c|}
$\begin{array}{c}\text { 豊浦·虹 } \\
\text { 田 }\end{array}$ \\
\end{tabular} & エゾパンウニ & $1.5 \sim 5$ & - & 1 & 0 \\
\hline \multirow{7}{*}{ 日本海 } & 増毛 & エソパフンウニ & $2 \sim 3.8$ & $\begin{array}{c}300 \sim 1,000 \\
30 \sim 300\end{array}$ & $\begin{array}{l}0.9 \\
0.6\end{array}$ & 0 \\
\hline & 宗谷 & $\begin{array}{l}\text { エゾバフンウニ } \\
\text { リシリコンブ }\end{array}$ & $2 \sim 3.5$ & - & \begin{tabular}{|c|}
$0.5 \sim 2.0$ \\
0.6 \\
\end{tabular} & 0 \\
\hline & 乙部 & エゾバフンウニ & $3 \sim 8$ & $300 \sim 1,000$ & 0.9 & 0 \\
\hline & 種丹西部 & エゾパフンウニ & $3 \sim 10$ & $300 \sim 1,000$ & 0.9 & 0 \\
\hline & 東利尻 & リシリコンブ & $3 \sim 9$ & $300 \sim 1,000$ & - & 0 \\
\hline & 南利尻 & エソバフンウニ & $3 \sim 7$ & $300 \sim$ & 0.9 & 0 \\
\hline & 新礼文 & リシリコンブ & $3 \sim 5$ & $300 \sim 1,000$ & 0.9 & 0 \\
\hline $\begin{array}{c}\text { オホーツ } \\
\text { ク海 }\end{array}$ & 枝幸 & エゾバフンウニ & $1 \sim 3$ & $300 \sim 1,000$ & - & 0 \\
\hline
\end{tabular}




\section{3. 実験方法}

\section{（1）実験模型}

実験は図-3に示す不規則波 2 次元水路（長さ $28 \mathrm{~m}$, 幅 $0.8 \mathrm{~m}$, 高さ $1.0 \mathrm{~m} ）$ において実施した。前面の海底 勾配は $1 / 30$ とし、これに続く水平床上に図一 4 に 示す増殖場の模型を設置した。増殖場の長さは $40 \mathrm{~cm}$ 、 設置水深は $12 ， 20$ および $28 \mathrm{~cm}$ の 3 種類とした。

増殖場の囲礁は直方体ブロック（縦 $5.0 \mathrm{~cm}$, 横 $5.0 \mathrm{~cm}$, 高さ $3.2 \mathrm{~cm})$ で作成し、その中に 2 層分の石 材を敷き並べた。

\section{（2）実験波}

実験波は、 1 波群 200 波を標準とし、ブレットシ ユナイダー・光易型スペクトルを目標とする不規則 波を用いた。実験周期は $\mathrm{T} 1 / 3=2.0 ， 2.4$ および $2.8 \mathrm{~s}$ の 3 種類で、現地換算すると $10.0,12.0$ および $14.0 \mathrm{~s}$ となる。波高については各水深条件に対して砕波領 域を含めた検討を行った。模型設置位置における有 義波高 $\mathrm{H} 1 / 3 \fallingdotseq 4.0 \sim 16.2 \mathrm{~cm}$ （現地換算 : $1.0 \sim 4.0 \mathrm{~m}$ ） の範囲で $5 \sim 6$ 種類に変化させて石材の移動状況を 目視観測した。以上の実験条件をまとめて表ー 2 に 示す。

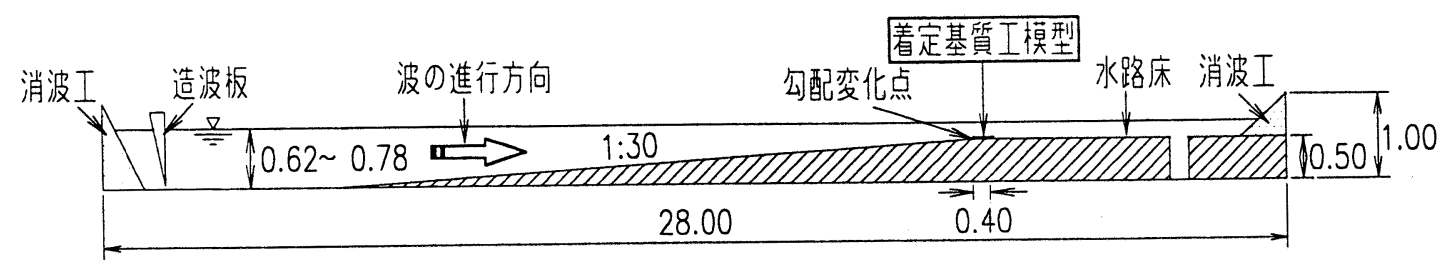

単位: $m$

\section{図 -3 実験水路}

\begin{tabular}{|rl|l|}
\multicolumn{4}{c|}{ 表 -2} & 波浪条件 \\
\hline 項 & \multicolumn{1}{c|}{ 目 } & 実験範囲（模型表示） \\
\hline 設置水深 & $\mathrm{h}(\mathrm{cm})$ & $12.0,20.0,28.0$ \\
有義周期 & $\mathrm{T} 1 / 3(\mathrm{~s})$ & $2.0,2.4,2.8$ \\
有義波高 & $\mathrm{H} 1 / 3 \quad(\mathrm{~cm})$ & $4.0 \sim 16.2$ \\
\hline
\end{tabular}

\section{（3）被害率の定義}

安定実験では、(1) 1 波群 200 波として徐々に大き な波高を作用させる方法、および (2)一定の波群を連 続的に 3,000 波作用させる方法、の 2 種類を用いた。 いずれの場合も一連の実験が終了するまで石材の並 べ直しは行わず、移動した石材の数を累積した。観 察においては石材一個長以上の距離を移動（抜け出 し）した場合を『被害』と定義した。なお、被害率 Dは設置した石の総質量に対する移動した石の総質 量の割合（\%）で示した。

\section{4. 石材の耐波安定性}

\section{（1）石材の移動特性}

写真 -1 は、 $T_{1} / 3=2.8 \mathrm{~s}, \mathrm{H}_{1} / 3=14.3 \mathrm{~cm}$ の波群が 200 
波作用した後の石材の移動状況を示したものである。 石材の移動個数は 39 個で、このときの被害率Dは 2. $2 \%$ と計算される。

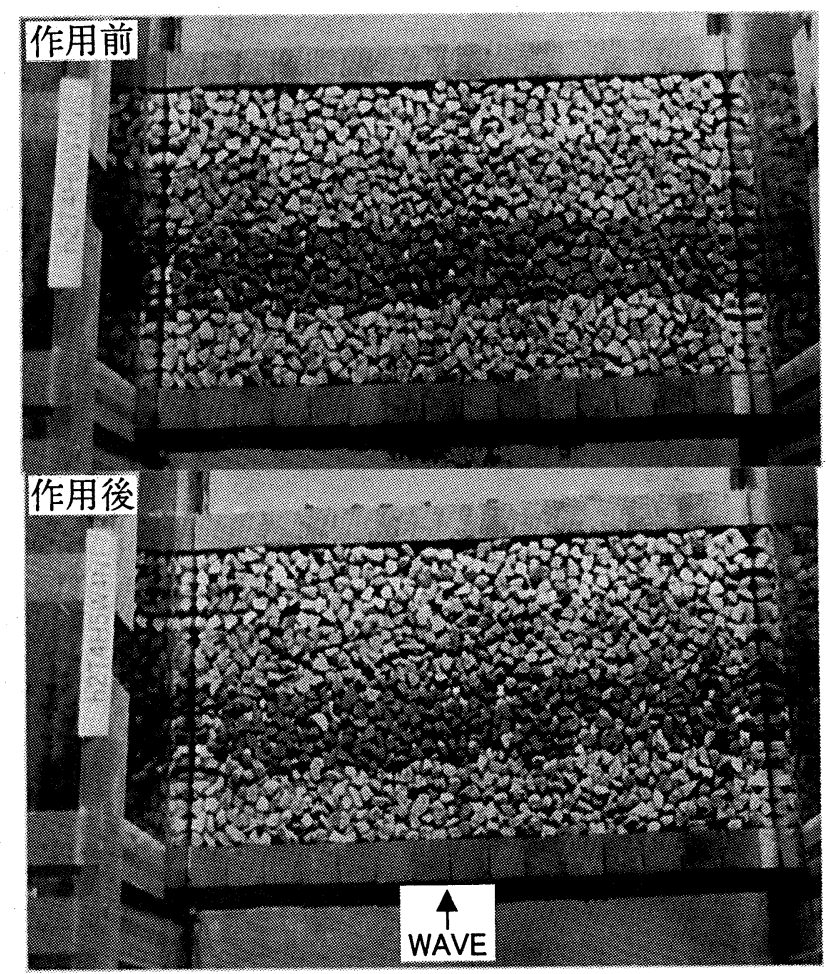

写真 - 1 石材の移動状況

図ー 6 は平均質量 Mが 6.1gの単一材を用いた場合 について、周期 $\mathrm{T} 1 / 3$ をパラメーターとして波高 $\mathrm{H} 1 / 3$ と被害率Dの関係を示している。表面波の影響を受 け易い水深 $\mathrm{h}=12 \mathrm{~cm}$ および $20 \mathrm{~cm}$ の条件では $\mathrm{T} 1 / 3=2.0 \mathrm{~s}$ に比べて周期の長い $2.4 \mathrm{~s}$ および $2.8 \mathrm{~s}$ の方が被害率 Dは大きくなっている。

図ー 7 は $\mathrm{h}=20 \mathrm{~cm}, T 1 / 3=2.8 \mathrm{~s}$ の条件に対して、単 一材（S-1）と中割石（S-2）の移動特性を比較し たものである。それぞれの平均質量 $M$ は $6.1 \mathrm{~g}$ になる ように調整してある。 $S-1$ と $S-2$ に大きな差はな く、中割石のような粒度分布を有する石材に対して も、単一材の実験結果を適用できると考えられる。

\section{（2）基質用石材の安定数}

混成堤基礎マウンド部や潜堤の被覆材の安定質量

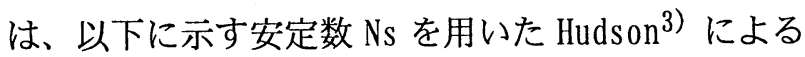
算定式で求められる。

$$
\mathrm{M}=\frac{\rho_{\mathrm{r}} \mathrm{H}_{1 / 3}{ }^{3}}{\mathrm{~N}_{\mathrm{s}}{ }^{3}\left(\mathrm{~S}_{\mathrm{r}}-1\right)^{3}}
$$
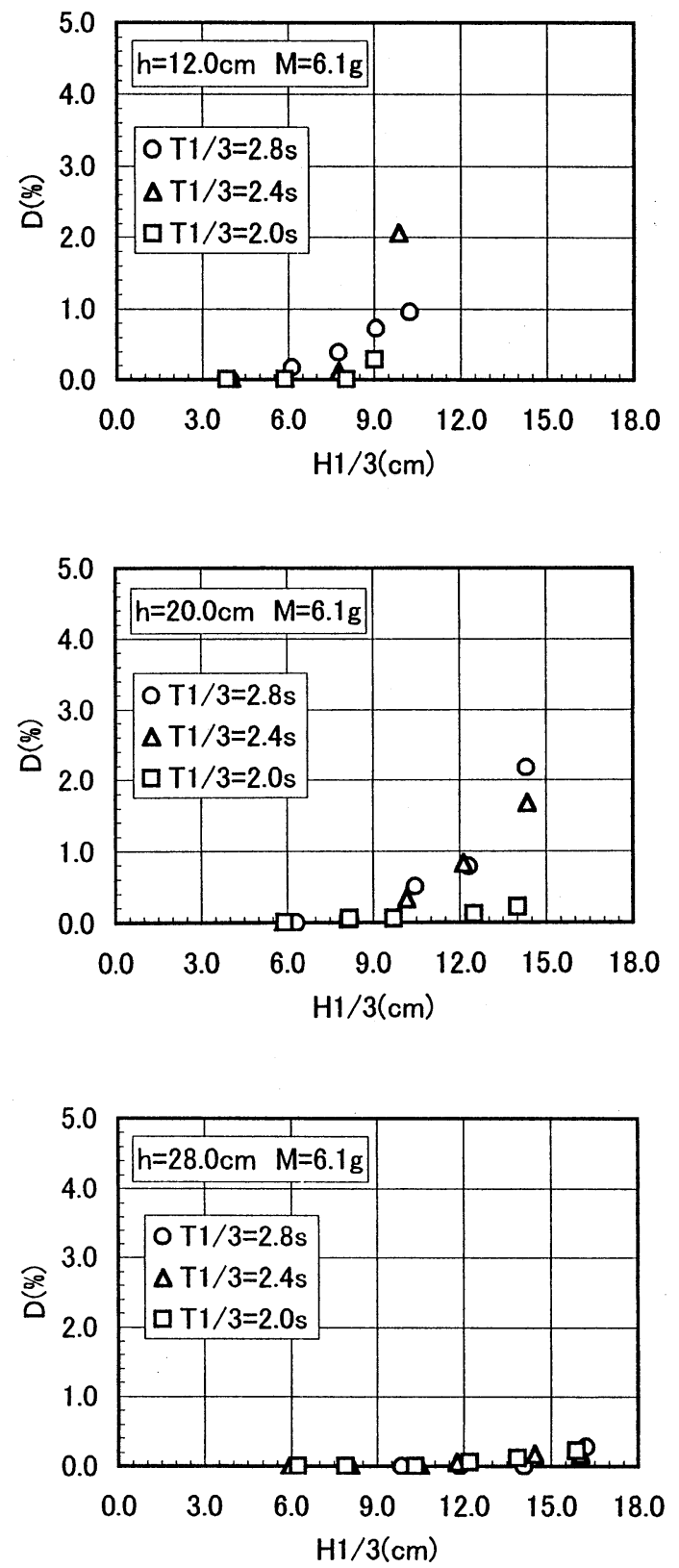

図一 6 波高と被害率（周期の影響）

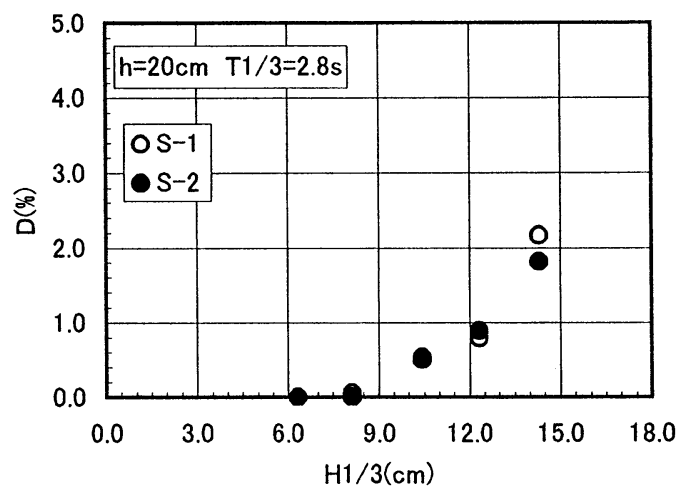

図-7 波高と被害率（粒度構成の影響） 
ここに、 $\mathrm{M}$ は被覆材の安定質量 $(\mathrm{t}), \rho \mathrm{r}$ は被覆材 の密度 $\left(\mathrm{t} / \mathrm{m}^{3}\right), \mathrm{S} \mathrm{r}$ は被覆材の海水に対する密度比, $\mathrm{H} 1 / 3$ は設計有義波高（m)，Ns は安定数である。

図一 8 は安定数 $\mathrm{N} \mathrm{s}$ と相対水深（h/L $1 / 3 ）$ の関係 を示したものである。○印で示されている実験值は 被害率 $\mathrm{D}=1 \%$ の条件に着目して、その安定限界波高と 基質用石材の質量を式（1）に代入し求めたもので ある。 $\mathrm{h} / \mathrm{L}_{1} / 3$ が小さくなるとともに底面近傍での 流速が増大するため Ns は小さくなる。

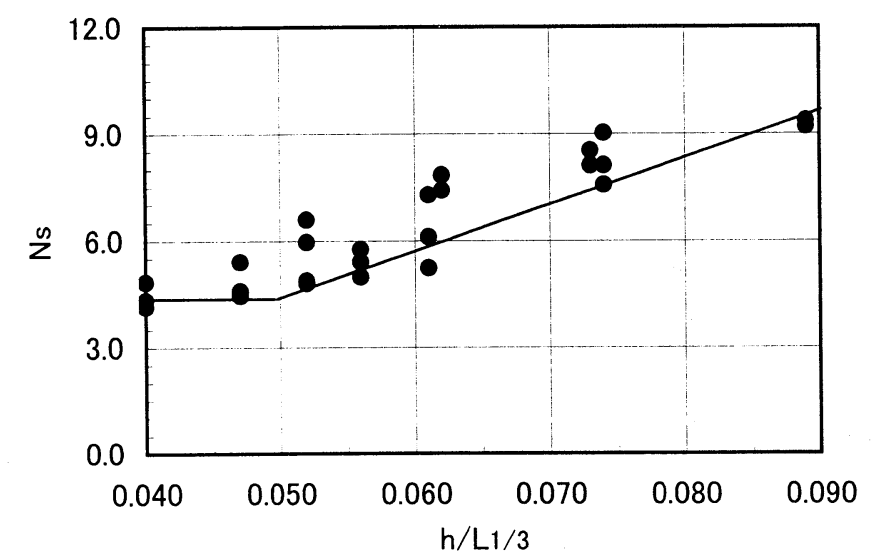

図 -8 安定数と相対水深の関係

図中の実線は実験結果の下限值を示したもので、 以下のように定式化される。なお、 $\mathrm{N}$ s の算定にあた っては実験を行った $\mathrm{h} / \mathrm{L}_{1 / 3}$ が 0.04〜0.09 の範囲 に適用可能である。

$$
\mathrm{Ns}= \begin{cases}4.5 & \left(0.04 \leqq \mathrm{~h} / \mathrm{L}_{1 / 3} \leqq 0.05\right) \\ 125 \cdot\left(\mathrm{h} / \mathrm{L}_{1 / 3}\right) & -1.75 \\ & \left(0.05 \leqq \mathrm{~h} / \mathrm{L}_{1 / 3} \leqq 0.09\right)\end{cases}
$$

\section{（3）安定限界を上回る条件に対する検討}

$\mathrm{h}=20 \mathrm{~cm}, \mathrm{~T}_{1} / 3=2.8 \mathrm{~s}$ の条件に対して、安定限界を上 回る波浪を 3,000 波（200 波を 15 回）作用させて、 単一材 $(S-1)$ および中割石 $(S-2)$ の被害特性を 調べた。使用した石材の平均質量 M は $6.1 \mathrm{~g}$ とし、波 高 $\mathrm{H} 1 / 3$ は $12.3 \mathrm{~cm}$ 及び $14.3 \mathrm{~cm}$ の 2 種類とした。提案 式より求めた安定限界波高をHD とすると、それぞれ
の波高は $1.2 \mathrm{HD}$ 及び $1.4 \mathrm{HD}$ となる。

図ー9は S-1 の被害率の変化を示している。最終 的な被害率 Dは $1.2 \mathrm{HD}$ で 1.2\%であるのに対し、1.4 HD では 9. 7\%まで進行している。また、図ー 10 に示す $S-2$ の場合も S-1 とほぼ同様な傾向を示しており、 1. $2 \mathrm{HD}$ で $1.4 \% 、 1.4 \mathrm{HD}$ では 8. $5 \%$ まで進行している。 以上示した実験結果を用いることにより、波浪条 件が厳しい場合に対しても、ある程度の変形を許容 することで安定質量に満たない石材を用いることが できる。

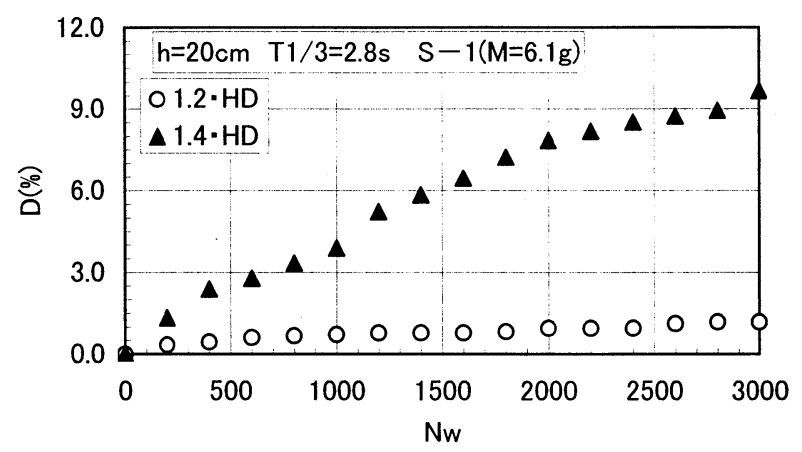

図-9 波数と被害率 $(S-1)$

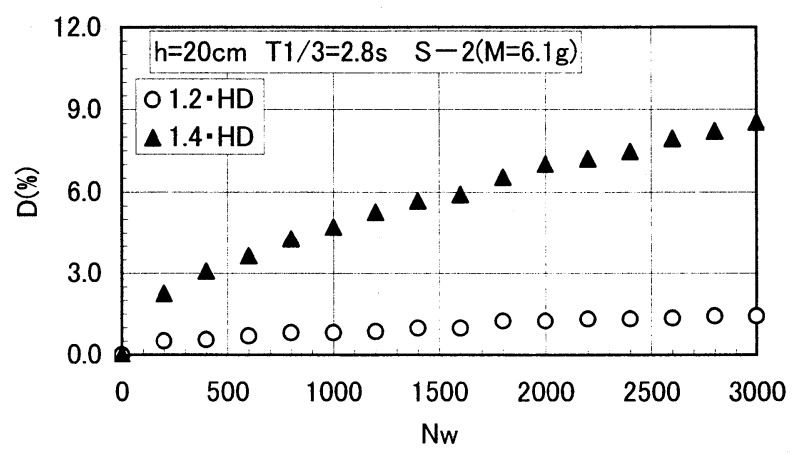

図-10 波数と被害率 $(S-2)$

\section{（4）既往の算定式との比較}

図ー 11 は基質用石材を水深 $\mathrm{h}=5.0 \mathrm{~m}\left(\mathrm{~T}_{1} / 3=14.0 \mathrm{~s}\right.$, 10. $0 \mathrm{~s} ）$ 及び $\mathrm{h}=3.0 \mathrm{~m} （ \mathrm{~T} 1 / 3=14.0 \mathrm{~s})$ の位置に設置す る場合の波高と安定質量の関係を示したものである。 図中の実線は提案式、点線は従来の算定式を表して いる。

両者の質量算定における傾向としては、従来の場 合は砕波形態（砕波, 非砕波）の感度が厳しく表さ れているのに対して、提案式では波高の増大と安定 質量の関係がなめらかになっている。両者の質量算 
定については被害の定義が異なるため直接的な比較 は難しいが、水深が比較的大きな地点で周期が短い 場合には、提案式では従来式に比べて安定質量が小 さく計算される傾向がある。
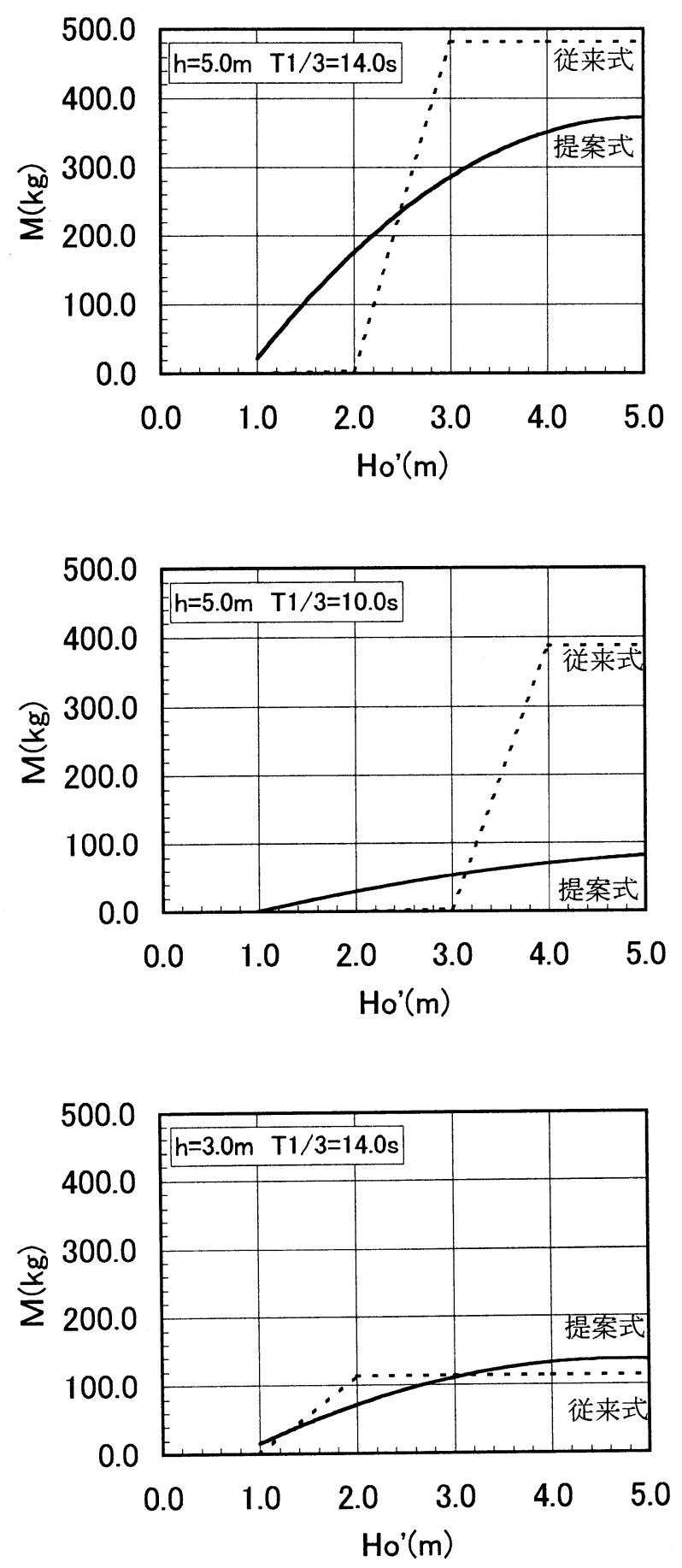

図-11 質量算定式の比較

\section{5. まとめ}

本研究で得られた主要な結論を以下に示す。

(1)磯根水産生物の着定基質用石材の安定質量算定 法を提案した。算定式はハドソン型とし、安定数 Ns を水深波長比 $\mathrm{h} / \mathrm{L}_{1 / 3}$ の関数として定式化し た。

(2)現地における中割石を対象とした検討を行い、石 材の粒度分布が安定性に及ぼす影響を明らかにし た。

(3)安定限界を上回る波浪の作用による基質用石材の 移動特性を明らかにした。

本研究では一般的な増殖場を対象として基質用石 材の耐波安定性を明らかにした。なお、今回は海底 勾配の影響を $1 / 30$ とした実験を示しているが、今 後引き続き、海底勾配の影響について検討する予定 である。また増殖場としての機能は、基質となる石 材の粒度構成によって大きく変化することが知られ ている。中割石や大割石といった一般的な規格とは 異なる石材の耐波安定性についても評価が必要であ る。

本研究での水理模型実験の実施にあたっては、北 海道東海大学海洋開発工学科の高橋良氏の協力を得 た。ここに記して謝意を表する次第である。

\section{参考文献}

1）社団法人全国沿岸漁業振興開発協会（1993）：沿 岸漁場整備開発事業施設設計指針

2) 明田定満, 高木儀昌, 田中一広 (1992) : 石材の 所要重量算定法に関する研究, 水産工学研究所技 報（水産土木）第 14 号, pp. 77〜88

3）水産庁（1986）：大規模増殖場造成事業調査総合 報告書昭和 60 年度版

4) Hudson, R. Y. (1959) :Laboratory Study of Rubble Mound Breakwaters, Proc. ASCE, Vol. 85, No. WW3, pp. $93-121$ 